\section{Boron Toxicity in Grapevine}

\author{
Uri Yermiyahu ${ }^{1}$ and Alon Ben-Gal \\ Institute of Soil Water and Environmental Sciences, Gilat Research Center, \\ Agricultural Research Organization, Mobile Post Negev 2, 85280, Israel
}

\author{
Pinchas Sarig \\ Jordan Valley Research and Development
}

Additional index words. Vitis vinifera, accumulation, plant growth, symptoms, yield

\begin{abstract}
Table grape production has recently become popular in arid and semiarid regions where conditions of salinity and excess boron (B) can be prevalent. This study addresses $B$ toxicity in grapevine to define toxicity symptoms and evaluate growth, production, and $B$ accumulation. The effect of excess B on grapevines (Vitis vinifera $L$. cv. Sugraone) was evaluated in a 4-year study in Israel's Jordan Valley. Vines were grown in 60-L perlite-filled containers and irrigated with complete nutrient solutions with four $B$ concentrations: $0.03,0.12,0.21$, and $0.31 \mathrm{~mm}$. Vines were monitored for growth, yield, and $B$ accumulation. Boron accumulation in leaves correlated with $B$ toxicity symptoms that materialized as chlorosis and necrosis of leaves beginning at their margins, reduced leaf size, and reduced internodal distance between adjacent leaves. Boron accumulated in grapevine leaves linearly as a function of increased $B$ in irrigation solution with time and with age of leaves. The highest $B$ levels were found at the end of each season and in the oldest leaves. No long-term (multiyear) effect of exposure to $B$ was observed because similar accumulation patterns and levels were found in each year of the experiment. Hence, consistently sampled diagnostic leaves and time of sampling for $B$ analysis is seen to be critical to provide valid comparisons between vines or over time. Boron supply influenced vine growth. At low levels of B $(0.03 \mathrm{~mm})$, canopy development was restricted but trunk size was not. At high levels of $B(0.21$ and $0.31 \mathrm{~mm})$, substantial visual symptoms of B toxicity were observed, and the rate of trunk growth was reduced, but pruning biomass was not influenced. Despite severe visual toxicity damage and reduced overall growth rates, commercial fruit yield of the vines remained unaffected by high environmental B levels.
\end{abstract}

Boron is essential for all plants but becomes toxic for many at concentrations, which can be found in natural and agricultural situations (Eaton, 1944; Gupta et al., 1985). Elevated amounts of B are often found in association with agriculture in arid regions where natural soil B levels are high and where water sources used for irrigation can contain additional B (El-Motaium et al., 1994; Nable et al., 1997). Municipal and other wastewater effluents used for irrigation are also sources of excess boron (Tsadilas, 1997). Boron uptake into plants occurs mainly through the roots with $\mathrm{B}$ as boric acid transported with the transpiration flow. Boron is considered highly immobile in most plants (Brown and Shelp, 1997) in that it is restricted to the transpiration stream (xylem) and accumulates at the end of that stream in leaves (Keren and Bingham, 1985; Nable et al., 1997). Boron toxicity symptoms are crop-specific, manifested in damage to tissues

Received for publication 7 June 2006. Accepted for publication 31 July 2006.

We thank the following for their support and assistance to this work: Israeli Chief Scientist Ministry of Agricultural and Rural Development (grants 301-256-99 and 301-359-02); Avi Stromza and Efraim Zipilevich (Jordan Valley R\&D); and Inna Faingold (Agricultural Research Organization).

${ }^{1}$ To whom reprint requests should be addressed; e-mail uri4@volcani.agri.gov.il. where it accumulates, and generally leads to chlorosis and necrosis beginning at the edges of mature leaves (Brown and Shelp, 1997; Nable et al., 1997). Sensitivity to B toxicity apparently involves a number of metabolic processes (Reid et al., 2004), including reduction in expansion in meristematic regions, development of necrotic areas of mature tissues (reducing photosynthetic capacity), and reduction of photosynthate supply of developing regions of the plant.

Little is known regarding the response of relatively high levels of boron in grapevines. Grapes have been defined as sensitive to excess B by Maas (1990) who qualified this definition through a threshold value of $B$ in soil solution of 0.5 to $0.75 \mathrm{mg} \cdot \mathrm{L}^{-1}$ ( 0.05 to $0.074 \mathrm{~mm}$ ) above which vegetative growth is reduced. Grapes share this sensitive categorization and threshold value with tree crops, including citrus (orange, grapefruit), stone fruits (apricot, peach, cherry, plum), avocado, persimmon, fig, walnut, and pecan. In Prunus rootstocks, B toxicity symptoms were found to correlate with stem B concentrations (El-Motaium et al., 1994) because B is phloem mobile in these species. In a pot experiment, leaf B concentrations of Prunus were not correlated with stem B or symptoms and no toxicity symptoms were observed on leaves. A study of Pecan (Carya illinoinensis) seedlings reported that irrigation water with greater than $0.1 \mathrm{~mm} B$ caused foliar toxicity and growth reduction (Picchioni et al., 1991).
First appearance of marginal chlorosis and necrosis in the pecans was reported to occur as leaf B content reached $500 \mathrm{mg} \cdot \mathrm{kg}^{-1}$ dry weight. Picchioni et al. (2000) suggested that incipient B toxicity occurs at lower concentrations than that inducing observable phytotoxicity in pecan and pistachio. Specific information regarding B toxicity in grapevines is extremely limited. Nikolaou et al. (1995) found toxicity symptoms in Victoria grapes when irrigating with water containing $0.4 \mathrm{~mm}$ B. In a nonscientific report, Peacock and Christensen (2005) wrote that irrigation water containing greater than $0.1 \mathrm{~mm} \mathrm{~B}$ may lead to toxicity in grapes and referred to $0.1 \mathrm{~mm}$ in saturated soil extract and 80 $\mathrm{mg} \cdot \mathrm{kg}^{-1}$ in leaf tissue as indicative of toxicity, although no experimental evidence was provided to support these conclusions.

The Jordan Valley of Israel is typical of arid and semiarid regions where potential for successful agriculture, including table grape production, is high and, as such, is a highly productive area where vineyards and orchards dominant the landscape. Also typical of many arid regions, the soils and water available for irrigation in the Jordan Valley are often saline (Dan et al., 1981) and the soils are prone to high levels of B in their mineral components. Release of this, soil B leads to high soil solution B concentrations (Yutal, 1990). There has been suspicion of B toxicity in table grape production of the Jordan Valley. Chlorotic leaf edges, typical of B toxicity symptoms (Eaton, 1944), are commonly observed during the vineyards' vegetative growing periods, especially at the end of seasons. Boron concentration in diagnostic leaves has been found to reach $900 \mathrm{mg} \cdot \mathrm{kg}^{-1}$ (Yermiyahu et al., 2002). Over the last few years, fruit production in the Jordan Valley has steadily declined and average fruit size decreased. In addition, lifespan of vineyards in the region seems to be substantially shorter as compared with other regions where the same varieties are grown (Pini Sarig, personal observation).

The objective of this study was to quantify the response of table grapes to conditions of excess boron. Specifically, grapevines (Vitis vinifera L. cv. Sugraone) were grown for 4 years in pots, irrigated with irrigation solution containing 4 B concentrations, and monitored for growth, yield, and B accumulation.

\section{Materials and Methods}

Boron-growing media interactions. To quantify absorption of B on the perlite growing media, a leaching experiment was conducted without plants in 2-L pots. Solutions containing $0.01 \mathrm{M} \mathrm{CaCl}_{2}$ at $\mathrm{B}$ concentrations of either 0.11 and $0.39 \mathrm{~mm}$ were applied to the perlite-filled pots. One half liter of solution was applied to the perlite in the pots twice a day for 3 consecutive days. Pots were covered to eliminate evaporation and allowed to sit for 3 weeks at which time two additional 0.5 -L irrigations were applied. During each solution application event, the leachate 
draining from the pots was collected and examined for B concentration.

Pot experiment. Six-month-old seedlings of an early-season, seedless table grape (Vitis vinifera L. cv. Superior (Sugraone) grafted on Ruggeri (Vitis berlandieri $\times V$. rupestris) rootstock were planted in $60-\mathrm{L}$ plastic containers at the Jordan Valley research station in Israel $\left(32^{\circ} 00^{\prime} \mathrm{N}, 35^{\circ} 26^{\prime} \mathrm{E}\right.$; elevation 140 m) on 15 Aug. 2000. The containers were equipped with drainage tubes and valves, a $5-\mathrm{cm}$ bottom layer of gravel covered with a mesh plastic screen, and filled with type 2 perlite granules ( 0 to $2 \mathrm{~mm}$ ).

An automatic irrigation system supplied water and fertilizer to each pot through six $2-\mathrm{L} \cdot \mathrm{h}^{-1}$ drippers. Three liters of irrigation water were applied nine times a day during daylight hours to each pot. Fertilizer was given continuously with the irrigation water at the following rates: $3.4 \mathrm{~mm} \mathrm{~N}(2.4$ and $1.0 \mathrm{~mm}$ as $\mathrm{N}-\mathrm{NO}_{3}$ and $\mathrm{N}-\mathrm{NH}_{4}$, respectively) 0.32 мм P, 0.77 mм K, $12.5 \mu \mathrm{m} \mathrm{Fe,} 6.2 \mu \mathrm{m}$ $\mathrm{Mn}, 2.6 \mu \mathrm{M} \mathrm{Zn}, 0.4 \mu \mathrm{M} \mathrm{Cu}$, and $0.2 \mu \mathrm{M}$ Mo. $\mathrm{Fe}, \mathrm{Mn}, \mathrm{Zn}$, and Mo were added as chelated complexes (Koratin Fetilizers and Chemicals, Ltd., Haifa, Israel). The source water contained naturally sufficient levels of $\mathrm{Ca}$ (1 $\mathrm{mm}), \mathrm{SO}_{4}(1 \mathrm{~mm})$, and $\mathrm{Mg}(0.3 \mathrm{~mm})$. Deviation of nutrient concentrations was less than $10 \%$ according to biweekly analysis of the irrigation water. Irrigation water $\mathrm{pH}$ was maintained between 6.3 and 6.5 using sulfuric acid (5\%). Boron treatments began $40 \mathrm{~d}$ after planting. Boron concentrations in irrigation water of: 0.03 (B0.03), 0.12 (B0.12), 0.21 (B0.21), and 0.31 (B0.31) $\mathrm{mm}$ were given to each of six repetitions in a split plot configuration. After 2 years, the vines were transferred to $100-\mathrm{L}$ pots filled with perlite. Irrigation was applied in excess. Every 2 weeks, irrigation water and drainage water collected over a 24-h period from each pot were analyzed for $\mathrm{EC}, \mathrm{pH}, \mathrm{NO}_{3}, \mathrm{NH}_{4}, \mathrm{P}, \mathrm{K}$, and $\mathrm{B}$. Vines were trellised on four-wire Y-shaped systems. Pruning was conducted in the first week of January each year as recommended by the local extension service and as practiced in local commercial vineyards on the basis of leaving two long canes of eight to 10 buds and four renewal spurs of two to three buds on each side of the trellising for each vine. Plant protection measures were conducted as recommended by the local vineyard extension service and as practiced by local commercial growers.

The Fall-season vegetative growth in the first year of the experiment after initiation of treatments was used to investigate initial effects of B on plant growth and on B uptake and accumulation in leaves. In January 2001 (110 d after initiation of treatments), leaves were sampled from quarter sections along transects of single shoots to compare B accumulation as a function of leaf age. Each year of the experiment, during the last week of January, vine trunk diameter was measured $10 \mathrm{~cm}$ above the grafting point, the vines were pruned, and pruning biomass was measured. Ten diagnostic leaves (the youngest fully mature leaf) per vine were sampled from the level of grape clusters and analyzed for B content several times a season. At the end of the experiment, roots were sampled. Sampled leaves and roots were washed with deionized water, dried at $60{ }^{\circ} \mathrm{C}$, and ground. Boron in solutions and $\mathrm{HCl}$ plant material extracts (Yermiyahu et al., 1995) was determined by the azomethene-H method (Page et al., 1982).

Data were analyzed using the JMP 5.0 software (SAS Institute, Cary, N.C.). Group differences for trunk circumference, pruning biomass, and fruit yield were assessed with analysis of variance with solution B concentration as a factor. Significance levels were set at $P=0.05$.

\section{Results}

Boron in root zone. Preliminary experiments showed that B in leachate became equal to $B$ of irrigation water after application of only two pore volumes for both 0.11 and $0.39 \mathrm{~mm}$ B irrigation water (Fig. 1). Under the experimental conditions of excess application of irrigation solution, B concentration and $\mathrm{EC}$ of the leachate in the pots containing grapevines were not allowed to exceed irrigation solution concentrations by more than
$20 \%$ (data not shown). It is therefore evident that the grapevines were exposed to the predetermined B levels soon after treatments commenced and that those levels remained consistent throughout the 4 years of the experiment

$B$ toxicity symptoms and accumulation. Each year, visual evidence of B toxicity was observed in vines receiving the two highest $\mathrm{B}$ irrigation solutions. Symptoms included smaller leaves, yellowing of leaf edges, and interveinal chlorosis followed by necrosis of leaves (Fig. 2A). The toxicity symptoms were found in plants receiving the highest $\mathrm{B}$ treatment $(0.31 \mathrm{~mm} \mathrm{~B}) \approx 1$ month after leaf emergence. The same symptoms appeared several weeks later on vines receiving the next highest $\mathrm{B}$ treatment (B0.21). Boron toxicity symptoms appeared on lower, mature and not on terminal leaves. Further into the season, visually reduced epical internodes were observed, particularly in the highest B level (Fig. 2B). By September, toxicity symptoms were found on the entire vine. No B toxicity symptoms were witnessed on vines irrigated with $\mathrm{B} 0.12$ and $\mathrm{B} 0.03$.

Boron content from leaves was assessed from quarter sections along transects of single branches during the autumn vegetative

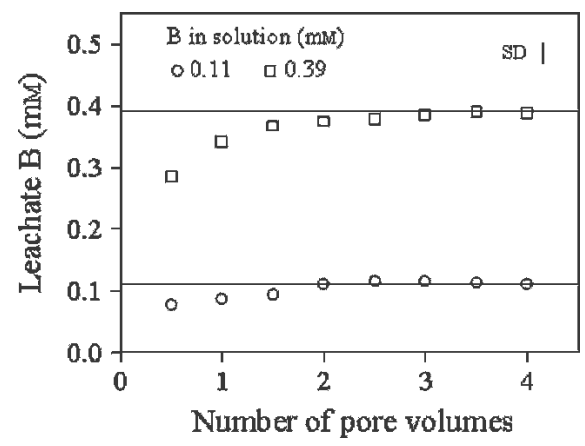

Fig. 1. Boron in leachate as a function of irrigation volume from a column study with perlite growing medium. Symbols are averages of experimental results and lines represent values of irrigation solution B. SD is maximum standard deviation.
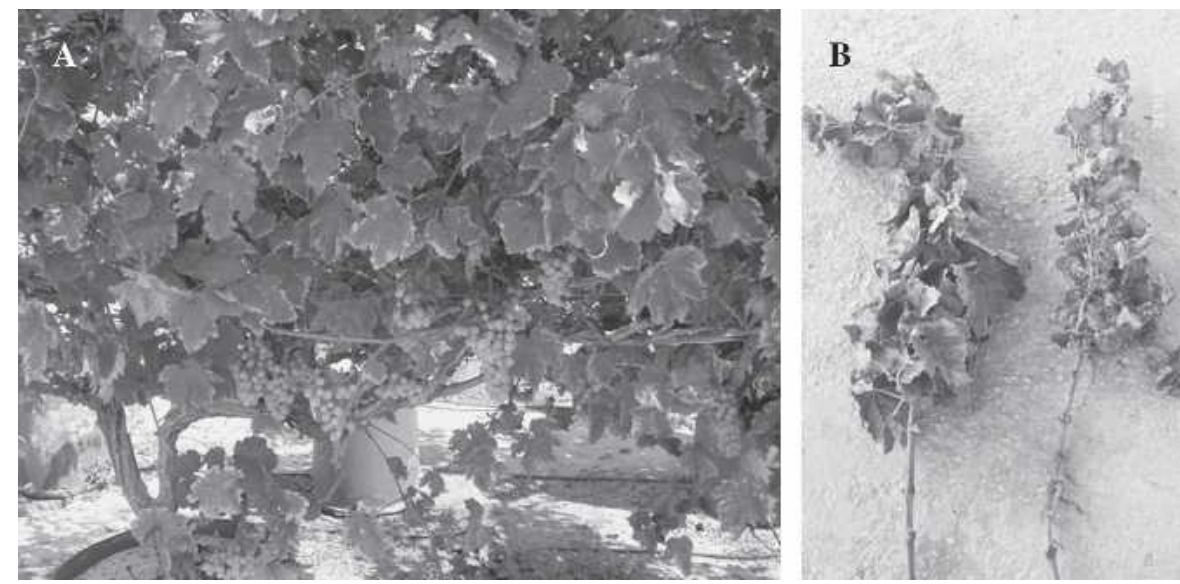

Fig. 2. Boron toxicity symptoms in container grown grapevine (Sugarone on Ruggeri) in the Jordan Valley, Israel. (A) Symptoms on leaves of vine irrigated with water containing $0.31 \mathrm{~mm}$ B photographed in June 2002. (B) Branch from grapevine irrigated with low boron $(0.03 \mathrm{~mm})$ solution (left) and high boron (0.31 mM) solution (right) photographed November 2001. 
growth period after initiation of treatments in the experiment's first season (Fig. 3). Boron was greater in mature leaves than in young leaves (Fig. 3) for vines receiving high $\mathrm{B}$ irrigation solution $(0.21$ and $0.31 \mathrm{~mm})$ but not for those receiving lower solution B levels $(0.03$ and $0.12 \mathrm{~mm})$. All leaves along the branches of $\mathrm{B} 0.03$ and $\mathrm{B} 0.12$ were $\approx 8$ and $10 \mathrm{mmol} \cdot \mathrm{kg}^{-1}$, respectively. Boron in leaves of B0.21 decreased significantly from 20.1 $\mathrm{mmol} \cdot \mathrm{kg}^{-1}$ in the most mature leaves to 12 in the youngest leaves. In B0.31 the decrease, also significant, was greater as leaf $\mathrm{B}$ ranged from 32.9 to $22.8 \mathrm{mmol} \cdot \mathrm{kg}^{-1}$. Boron in each age of leaf was consistently higher as a function of increased $\mathrm{B}$ in irrigation solution. Increased B accumulation as a function of $\mathrm{B}$ in solution was also found for diagnostic leaves sampled over single seasons (Fig. 4) and across all the years of the experiments (Fig. 5).

Boron concentration of diagnostic leaves increased linearly with increasing solution B concentration during every sampling date and growing season as illustrated in Figure 4 for data from the final growing season (2003). Leaf concentration of B increased with time within the 2003 season at each B solution concentration. The extent of $\mathrm{B}$ accumulation with increased B in solution increased with time as seen in the slopes of the linear regression analysis (Fig. 4). Although the intercepts (B 0 leaf content) of the linear regressions were not different for the four sampling dates, the slopes (increased leaf B per unit increase in solution B) increased from $25.4 \mathrm{mmol} \cdot \mathrm{kg}^{-1} \cdot \mathrm{mm}^{-1}$ in March to $456 \mathrm{mmol} \cdot \mathrm{kg}^{-1} \cdot \mathrm{mm}^{-1}$ in September.

Annual seasonal dynamics of B accumulation in leaves was similar for all the years of the experiment. To demonstrate this phenomenon, B concentration of diagnostic leaves is presented in Figure 5 for the closest sets of sampling dates during the 2001, 2002, and 2003 growing seasons. About 1.5 months after leaf emergence, B was lower in 2003 for $\mathrm{B} 0.21$ and B0.31 treatments as compared with the previous 2 years (Fig. 5A) However, no such difference was found for subsequent July and September sampling dates (Fig. 5B, C).

Root dry matter B concentrations measured from samples at the conclusion of the experiment showed a linear increase with irrigation solution B (Fig. 6), which was similar to that of leaf B concentrations. Root $\mathrm{B}$ concentration ranged from $5 \mathrm{mmol} \cdot \mathrm{kg}^{-1}$ in the lowest to $50 \mathrm{mmol} \cdot \mathrm{kg}^{-1}$ for the highest $\mathrm{B}$ solution concentrations. Root B concentration was $\approx 40 \%$ of that found in leaves in September samplings.

Grapevine growth and yields. Trunk circumference increased from year to year. Trunks of B0.03 vines grew from 20- to 50 $\mathrm{mm}$ circumference between 2001 and 2002 and then to $69 \mathrm{~mm}$ in 2003 and $80 \mathrm{~mm}$ in 2004. Boron in irrigation water had no effect on trunk circumference in the first 2 years of treatments. In the third and fourth years, increased B in irrigation solution resulted in linear decrease in vine trunk size (Fig. 7). For

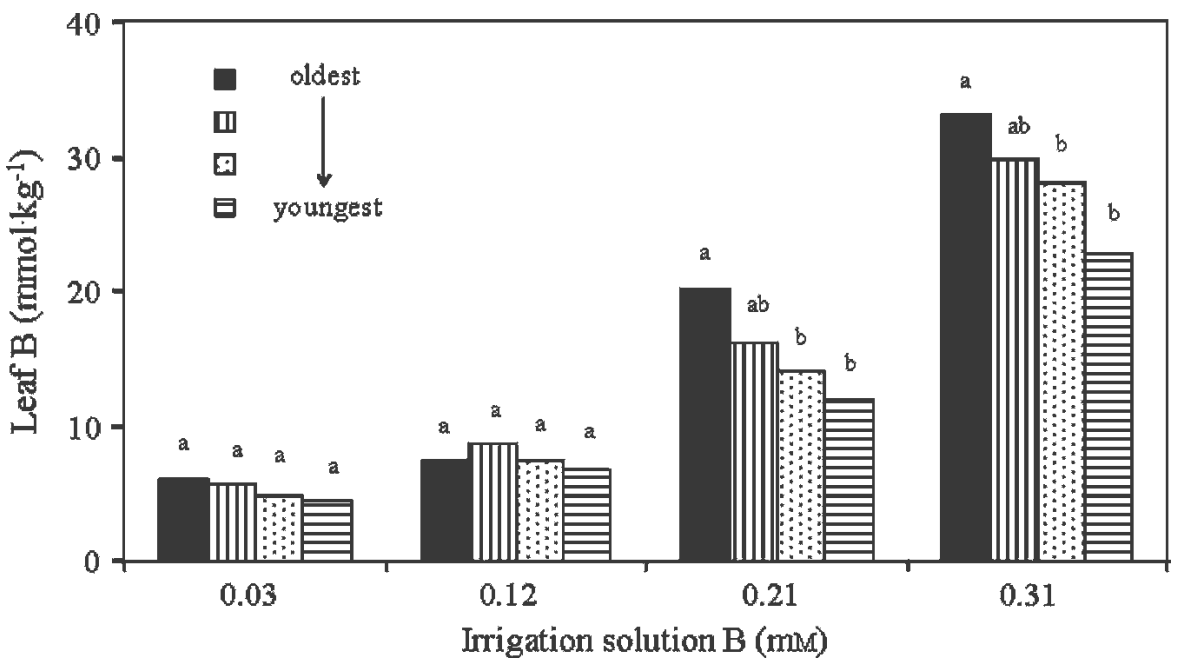

Fig. 3. Boron content in grapevine leaves of different developmental stages sampled along single branches $110 \mathrm{~d}$ after initiation of irrigation with B-laden water in the experiment's initial season. Different lower case letters indicate significantly different averages between samples in a single B treatment $(n=6)$.

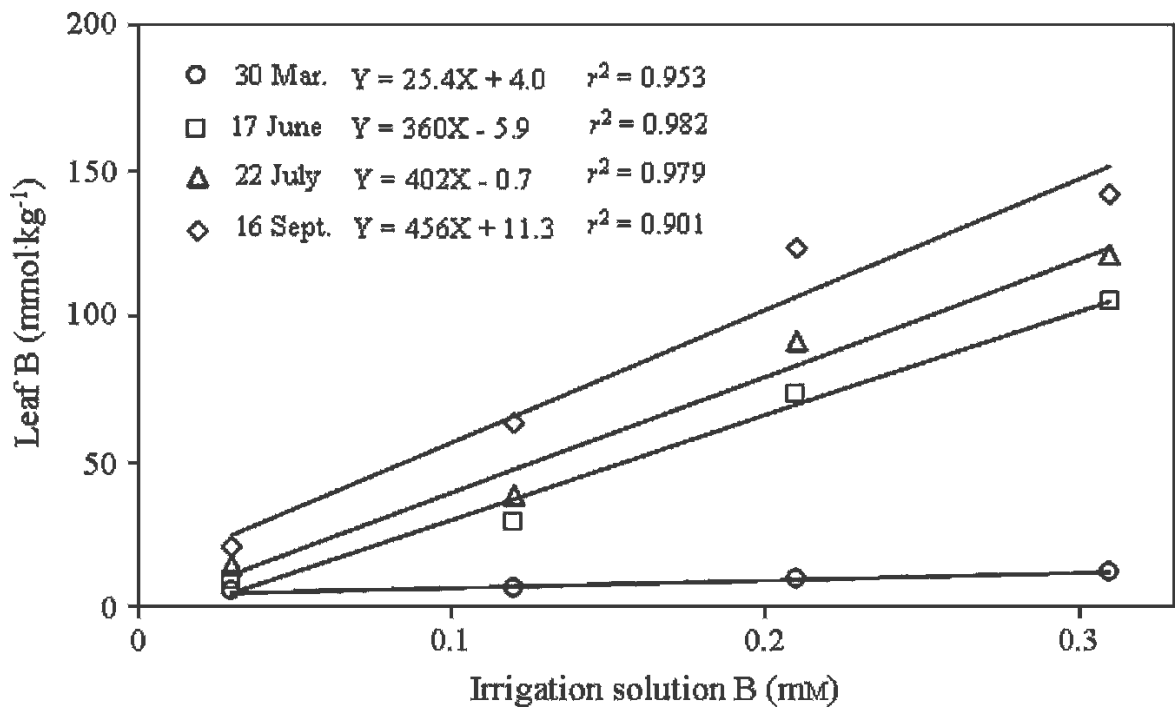

Fig. 4. Boron in dry matter of grapevine diagnostic leaves for four sampling dates during the 2003 growing season. Symbols are averages of experimental results and lines are best fit linear regression $(P \leq 0.05)$.

both years, the response curves were statistically highly significant $(P \leq 0.05)$. The cumulative effect of $\mathrm{B}$ on trunk circumference increased with time as seen in the decreasing slopes of regression lines.

Pruning biomass in the first year was small (Table 1), reflecting the relatively short time between planting (August) and pruning (January). In the subsequent years, annual pruned biomass was 4 to $6 \mathrm{~kg}$ per vine. In the first 3 years, no significant differences were found between B treatments. There was significantly greater pruning biomass in B0.21 compared with B0.03 in 2004. A similar but nonsignificant trend was evident in 2002 and 2003 when pruning biomass increased with initial increase in solution $B$ and then decreased as B in solution was further increased. Cumulative pruning biomass was greater at $\mathrm{B} 0.21$ than $\mathrm{B} 0.03$.

Annual fruit yields ranged from 1 to 14 $\mathrm{kg} /$ vine (Table 2). In 2002, yields were particularly low, reaching only 1 to $2 \mathrm{~kg}$ / vine; 2003 yields reached 9 to $14 \mathrm{~kg} / \mathrm{vine}$ and 2004 yields were 4.5 to $5.5 \mathrm{~kg} /$ vine. No differences were found among vines irrigated with different $\mathrm{B}$ solution concentrations in yields of harvested grapes except for an increased yield in the highest B treatment in 2003 . The exceptionally high yield of $14.2 \mathrm{~kg}$ for B0.31 in 2002 lead to significant difference between that treatment and the other three for cumulative fruit yield over the course of the experiment.

\section{Discussion}

The data on growth, production, and B content of the grapevines grown in perlite media in container experiment contributes valuable information regarding potential and nature of $\mathrm{B}$ toxicity in table grapes. In addition to a novel illustration of B toxicity in grapevines, the data specifically reveal 

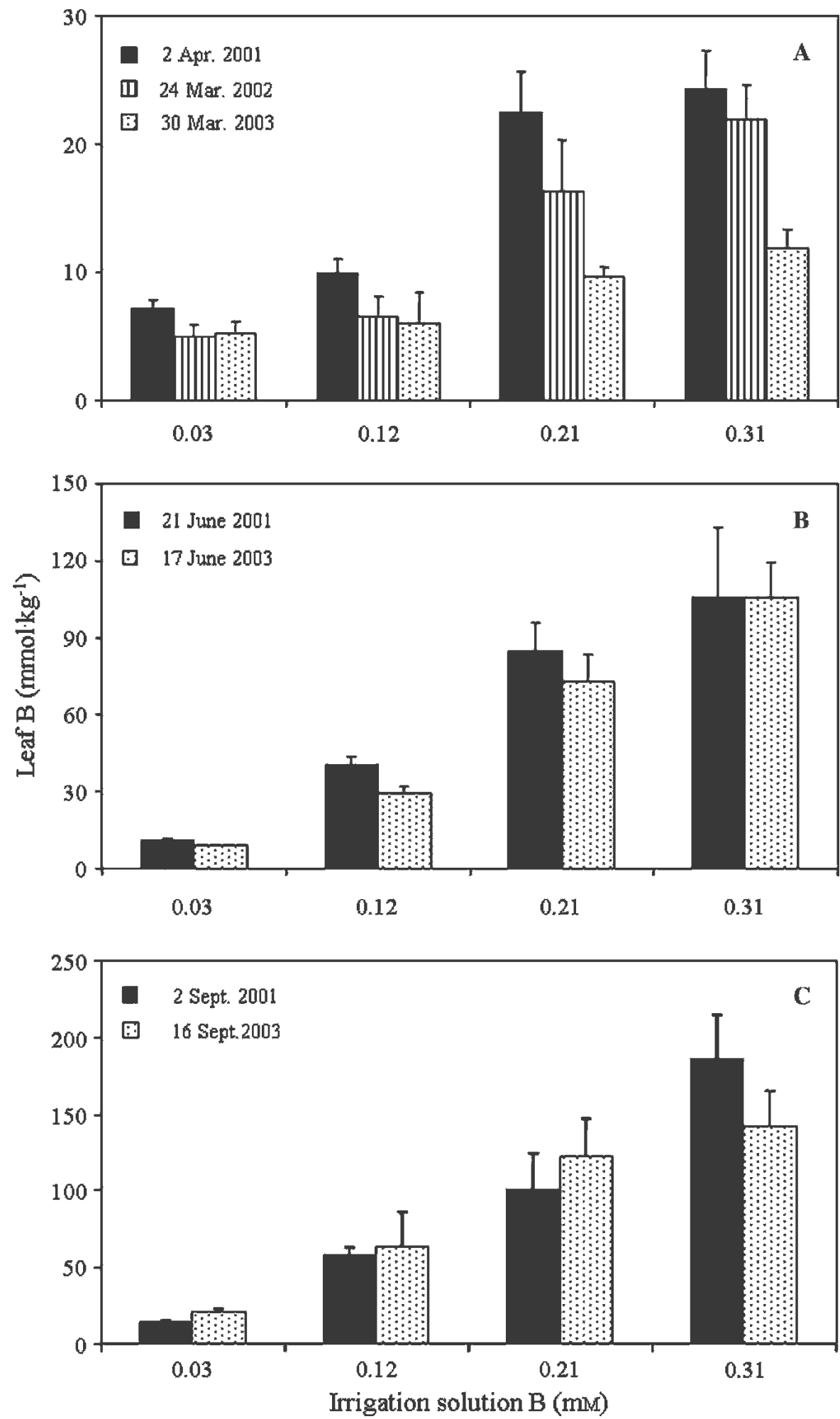

Fig. 5. Boron in dry matter of grapevine diagnostic leaves as a function of B in irrigation solution at sampling dates representing equivalent growth stage during successive years. March-April (A), June (B), and September (C). Columns are averages of experimental results; error bars show standard deviations $(n=6)$.

relationships between $\mathrm{B}$ accumulation and toxicity and between toxicity symptoms and agronomic and economic consequences.

Boron toxicity materialized as B concentrated in leaves and was accompanied by visually apparent damage of leaves and stems. The symptoms found in leaves were typical of those of other crops in which the dominant visual feature is the chlorosisnecrosis of margins of mature leaves (Gupta et al., 1985). Evidence of negative effects of $\mathrm{B}$ on grapevines, including B toxicity symptoms (Fig. 2), and of B uptake and accumulation were apparent even in the initial year, in which relatively short-term autumn vegetative growth alone without any reproductive stages was monitored. In this first season, B concentration of leaves increased with age as measured from samples transecting the shoots (Fig. 3). As B exposure levels increased, differences in leaf $\mathrm{B}$ within the vine were amplified. Similar results (data not shown) were found in subsequent seasons when vegetative growth was accompanied by fruit production indicating that the trends seen in Figure 3, if not the values of B, are repeatable. The use of consistently sampled diagnostic leaves for $\mathrm{B}$ analysis is therefore critical to provide valid comparisons among vines or over time. Timing of sampling is also important as the $\mathrm{B}$ in diagnostic leaves increased over the course of a season (Fig. 4).

Boron in leaves and roots increased linearly as a function of B in solution (Figs. 5 and 6). Similar B accumulation as a function of environmental B level has been reported in toxicity studies on crops, including tomato (Ben-Gal and Shani, 2003; Francois, 1984), pepper (Yermiyahu et al., 2003) sunflower (Blamey et al., 1997), melon (Goldberg et al., 2003), and wheat barley and sorghum (Bingham et al., 1985) but not in Prunus species (El-Motaium et al., 1994) in which B is phloem mobile.

Boron accumulation in leaves was seen to be a function of $\mathrm{B}$ in solution and time with higher B found in older leaves than younger within a vine (Fig. 3). This is similar to uptake patterns of B reported in studies of B deficiency on grapevine (Scott and Schrader, 1947) and to patterns found in other plant species (Brown and Shelp, 1997; Dannel et al., 1999). Absolute levels of B in leaves (Figs. 4 and 5) were high compared with other crops as was the B content of roots sampled at the end of the experiment (Fig. 6). Although this may indicate relatively high rates of B uptake by grapevines, it likely is more an indication of the importance of transpiration demand on B uptake because the local climate conditions caused particularly high daily and seasonal water demand. The measured leaf B contents were consistent with those sampled from local 10- to 15-yearold commercial vineyards grown in soils with naturally high $\mathrm{B}(\approx 0.1 \mathrm{~mm}$ in saturated paste $)$ in which B content in diagnostic leaves was seen to increase from 10 to $17 \mathrm{mmol} \cdot \mathrm{kg}^{-1}$ in the beginning of the season to as much as $200 \mathrm{mmol} \cdot \mathrm{kg}^{-1}$ at the end of the season (Yermiyahu et al., 2002).

Two methods of monitoring vegetative growth of grape vines - trunk size and pruning biomass - were applied. Increasing B in irrigation restricted growth of trunks after 2 years (Fig. 7) but did not cause reduction in pruning biomass (Table 1). Trunk size is an accumulative parameter reflecting total plant growth, whereas pruning biomass measures woody growth of a single year. Damage by B is expected to occur in the leaves and develops over the course of each season. The visual toxicity symptoms and measured plant growth parameters were not only repeated but returned at the same B levels year after 


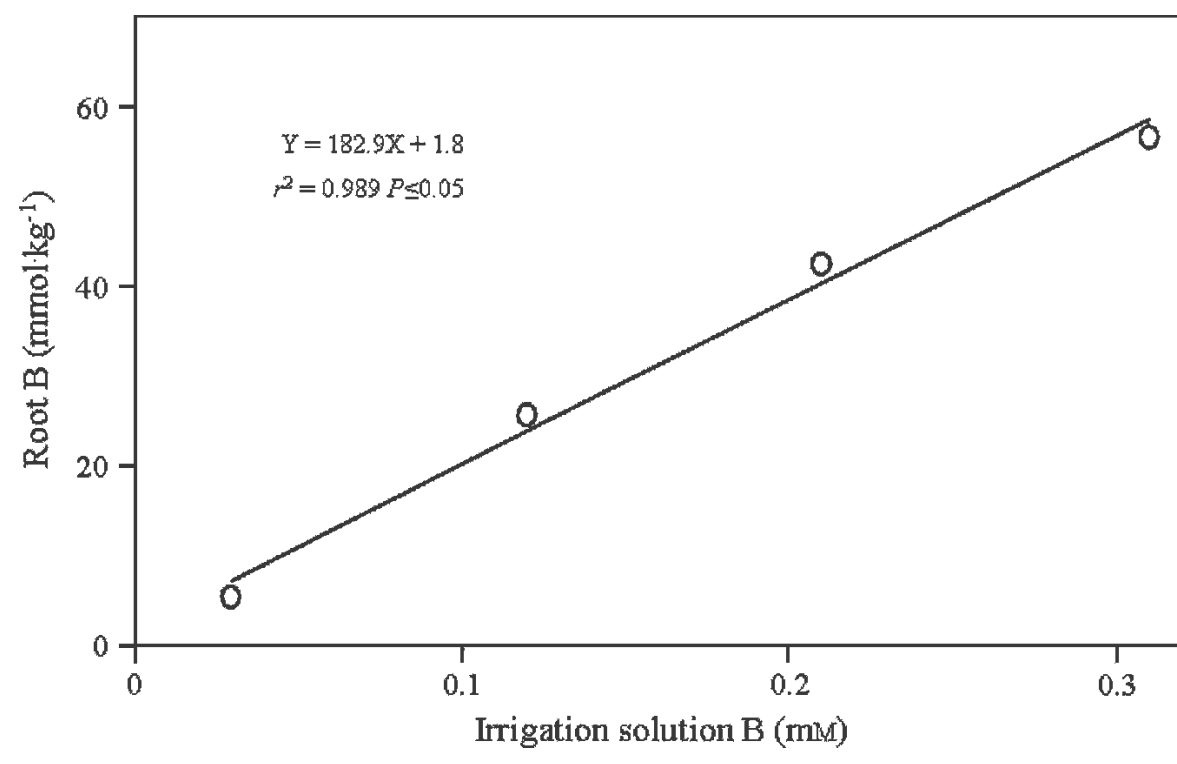

Fig. 6. Boron content in grapevine roots as a function of irrigation solution B after 4 years of irrigation treatments. Symbols are averages of experimental results and line is best fit linear regression.

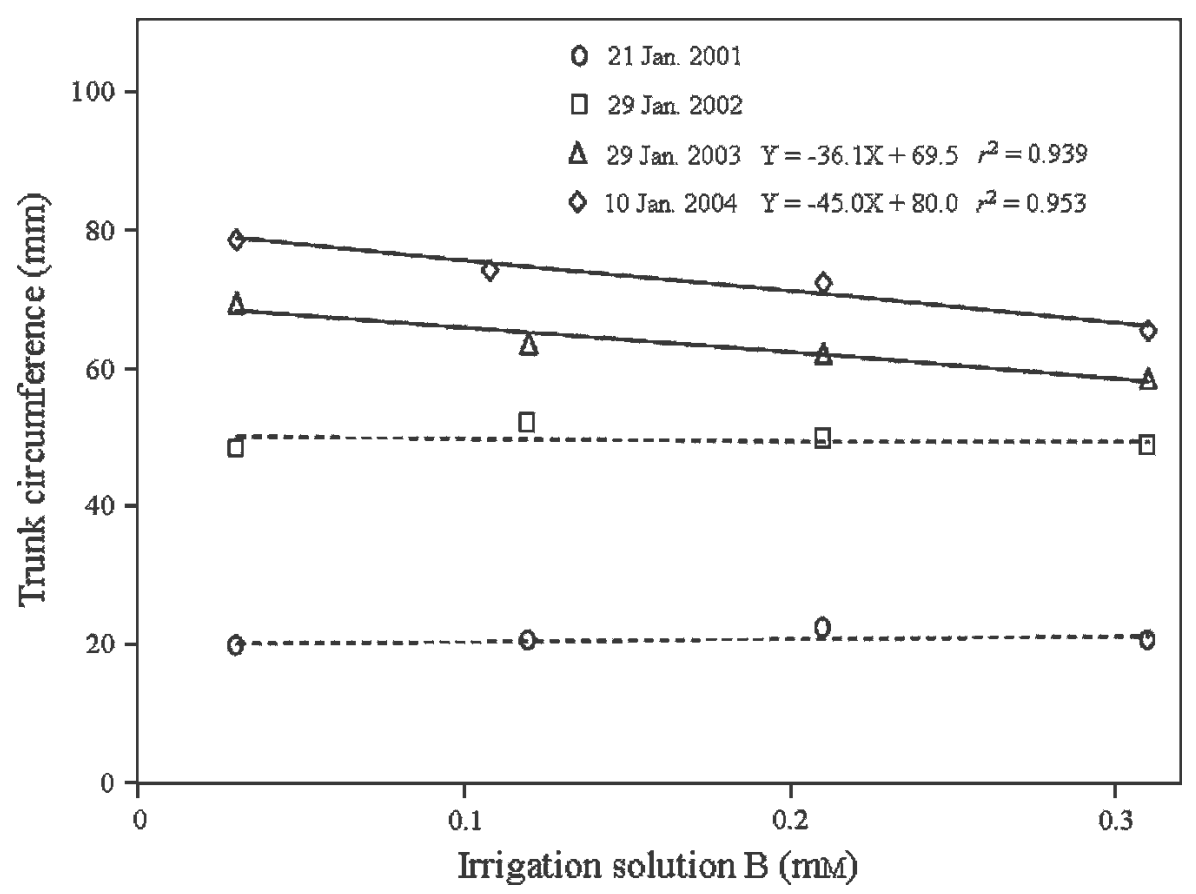

Fig. 7. Circumference of vine trunks as a function of irrigation solution B concentration measured during pruning for the 4 consecutive years of the experiment. Symbols are averages of experimental results and lines are best fit linear regression. Solid lines are given for significant $(P \leq 0.05)$ relationships.

Table 1. Annual and total pruned biomass for 4 years of experimental treatments of application of B-laden irrigation water to grapevines in a pot experiment ${ }^{\mathrm{z}}$

\begin{tabular}{lccccc}
\hline $\begin{array}{l}\text { Boron in irrigation } \\
\text { solution } \\
(\mathrm{mM})\end{array}$ & $\begin{array}{c}\text { 21 Jan. 2001 } \\
(\mathrm{kg})\end{array}$ & $\begin{array}{c}\text { 29 Jan. 2002 } \\
(\mathrm{kg})\end{array}$ & $\begin{array}{c}\text { 29 Jan. 2003 } \\
(\mathrm{kg})\end{array}$ & $\begin{array}{c}\text { 10 Jan. 2004 } \\
(\mathrm{kg})\end{array}$ & $\begin{array}{c}\text { Total } \\
(\mathrm{kg})\end{array}$ \\
\hline 0.03 & $1.4 \mathrm{a}$ & $4.6 \mathrm{a}$ & $4.5 \mathrm{a}$ & $3.5 \mathrm{~b}$ & $14.0 \mathrm{~b}$ \\
0.12 & $1.3 \mathrm{a}$ & $5.7 \mathrm{a}$ & $5.6 \mathrm{a}$ & $4.5 \mathrm{ab}$ & $17.1 \mathrm{ab}$ \\
0.21 & $1.3 \mathrm{a}$ & $5.7 \mathrm{a}$ & $5.0 \mathrm{a}$ & $6.3 \mathrm{a}$ & $18.3 \mathrm{a}$ \\
0.31 & $0.9 \mathrm{a}$ & $3.9 \mathrm{a}$ & $5.0 \mathrm{a}$ & $6.3 \mathrm{a}$ & $16.1 \mathrm{ab}$ \\
\hline
\end{tabular}

${ }^{\mathrm{z}}$ Different lower case letters indicate significantly different averages between treatments in a single year $(n=6)$. year. The "seasonal" measurements of B accumulation in leaves and mass of pruned woody vegetative material remained constant over the years. Fruit yields that varied from year to year had no correlation with B treatments. The only evidence of accumulated or intensified effects of B exposure was found in the reduced trunk size measurements that developed in vines irrigated with high $B$ solutions and that were amplified over the years. It is not clear whether the reduced vine size as represented in trunk circumference would have any eventual long-term effect on the seasonal parameters of vegetative growth or yield. In the particular case of the Jordan Valley, it appears that vegetative growth is in excess of that needed to provide sufficient base for successful reproductive growth and fruit production and that even relative severe damage to leaves does not reduce either annual production of woody branches or fruit.

The data indicate that, despite visual toxicity symptoms, B in concentrations thought to be potentially problematic may rather be beneficial. Pruning biomass of the vines receiving the lowest $\mathrm{B}(0.03 \mathrm{~mm})$ consistently was lower than that of the next B levels $(0.12$ and $0.21 \mathrm{~mm})$ suggesting that the base level was insufficient to provide optimum vegetative growth. In turn, fruit yield data indicated some advantage to the highest B concentration $(0.31 \mathrm{~mm})$ over the others as a result of the particularly high yield of that treatment during the 2003 harvest. Possible explanations include either a specific, high requirement for $B$ of reproductive tissues or reduced vegetative growth providing more mineral nutrients for berry formation. Alternatively, reduction in leaf area may limit transpiration, thereby reducing plant water stress. We suggest caution in inferences based on these theories and on the results because the increased yield with high B was found only for a single treatment and there was no indication of the result repeating itself the next year. Increased reproductive activity could possibly have been a one-time response to the stress conditions experienced.

In summary, B accumulation in leaves was found to correlate with B toxicity symptoms, which included chlorosis and necrosis beginning with leaf margins, reduced leaf size, and diminished internodal distance between leaves. Boron accumulated in grapevine leaves linearly as a function of increased $\mathrm{B}$ in irrigation solution with time and with age of leaves. The highest B levels were found at the end of each season and in the oldest leaves. Boron accumulation patterns and levels were repeated for each year of the experiment. Boron influenced vine growth; at low levels of B $(0.03 \mathrm{~mm})$, canopy development was restricted but trunk size was not. At high levels of B (0.21 and $0.31 \mathrm{~mm})$, substantial visual symptoms of B toxicity were observed, pruning biomass was not influenced, and total accumulated biomass production measured by trunk size was reduced over time. In the present experiment, in 
Table 2. Annual and total grape yield for 3 years of experimental treatments of application of B-laden irrigation water to grapevines in a pot experiment ${ }^{2}$

\begin{tabular}{lcccc}
\hline $\begin{array}{l}\text { Boron in irrigation } \\
\text { solution } \\
(\mathrm{mM})\end{array}$ & $\begin{array}{c}2002 \\
(\mathrm{~kg})\end{array}$ & $\begin{array}{c}2003 \\
(\mathrm{~kg})\end{array}$ & $\begin{array}{c}2004 \\
(\mathrm{~kg})\end{array}$ & $\begin{array}{c}\text { Total } \\
(\mathrm{kg})\end{array}$ \\
\hline 0.03 & $0.9 \mathrm{a}$ & $8.9 \mathrm{~b}$ & $5.0 \mathrm{a}$ & $14.8 \mathrm{~b}$ \\
0.12 & $0.8 \mathrm{a}$ & $9.6 \mathrm{~b}$ & $4.7 \mathrm{a}$ & $15.1 \mathrm{~b}$ \\
0.21 & $1.6 \mathrm{a}$ & $9.1 \mathrm{~b}$ & $4.4 \mathrm{a}$ & $15.1 \mathrm{~b}$ \\
0.31 & $1.2 \mathrm{a}$ & $14.2 \mathrm{a}$ & $5.5 \mathrm{a}$ & $20.9 \mathrm{a}$ \\
\hline
\end{tabular}

${ }^{\mathrm{Z}}$ Different lower case letters indicate significantly different averages between treatments in a single year $(\mathrm{n}=6)$.

which water and nutrients were not limiting and the climate was conducive to vegetative growth, despite even severe visual toxicity damage and reduced overall growth rates, commercial fruit yield of the vines remained unaffected by high environmental B levels.

\section{Literature Cited}

Ben-Gal, A. and U. Shani. 2003. Water use and yield of tomatoes under limited water and excess boron. Plant Soil 256:179-186.

Bingham, F., J. Strong, J. Rhoades, and R. Keren. 1985. An application of the Maas-Hoffman salinity response model for boron toxicity. Soil Sci. Soc. Amer. J. 49:672-674.

Blamey, F.P.C., C.J. Asher, and D.G. Edwards. 1997. Boron toxicity in sunflower. p. 145-149. In: Bell R.W. and B. Rerkasem (eds.). Boron in soils and plants. Kluwer Academic Publishers, Dordrecht, The Netherlands.

Brown, P.H. and B.J. Shelp. 1997. Boron mobility in plants. Plant Soil 193:85-101.

Dan, J., R. Gerson, H. Koyumdjisky, and D. Yaalon. 1981. Aridic soils of Israel; Properties, genesis and management. Special Publication No. 190 Agricultural Research Organization, The Volcani Center, Bet Dagan, Israel.

Dannel, F., H. Pfeffer, and V. Romheld. 1999. Distribution within the plant or compartmentation does not contribute substantially to the detoxification of excess boron in sunflower
(Helianthus annus). Aust. J. Plant Physiol. 26:95-99.

Eaton, F.M. 1944. Deficiency, toxicity, and accumulation of boron in plants. J. Agric. Res. 69:237-277.

El-Motaium, R., H. Hening, and H.B. Patrick. 1994. The relative tolerance of six prunus Rootstock to boron and salinity. J. Amer. Hort. Sci. 119:1169-1175.

Francois, L.E. 1984. Effect of excess boron on tomato yield, fruit size, and vegetative growth. J. Amer. Soc. Hort. Sci. 109:322-324.

Goldberg, S., P.J. Shouse, S.M. Lesch, C.M. Grieve, J.A. Poss, H.S. Forster, and D.L. Suarez. 2003. Effect of high boron application on boron content and growth of melons. Plant Soil 256:403-411.

Gupta, U.C., Y.W. James, C.A. Cambell, A.J. Leyshon, and W. Nicholaichuk. 1985. Boron toxicity and deficiency: A review. Can. J. Soil Sci. 65:381-409.

Keren, R. and F.T. Bingham. 1985. Boron in water, soil and plants. Adv. Soil Sci. 1:229-276.

Maas, E.V. 1990. Crop salt tolerance. p. 262-304. In: Tanji (ed.). Agricultural salinity assessment and management. ASCE Manuals and Reports on Engineering No 71. ASCE, N.Y. Boron toxicity. Plant Soil 198:181-198.

Nikolaou, N., A. Mattheou, and N. Karagiannidis. 1995. Boron toxicity in grapevines as a result of irrigation: Effect of rain on leaching. Porgres. Agricole. et Viticole. 112:111-116.
Nable, R.O., G.S. Banuelos, and J.G. Paull. 1997.
Page, A.L., R.H. Miller, and D.R. Keeney. 1982. Methods of soil analysis part 2, chemical and microbiological properties. Soil Sci. Soc. of Am. Am. Soc. of Agronomy, Madison, Wis.

Peacock, W.L. and L.P. Christensen. 2005. Drip irrigation can effectively apply boron to San Joaquin Valley vineyards. California Agr. 59:188-191.

Picchioni, G.A., H. Karaca, L.G. Boyse, B.D. McCaslin, and E.A. Herrera. 2000. Salinity, boron, and irrigated pecan productivity along New Mexico's Rio Grande basin. J. Environ. Qual. 29:955-963.

Picchioni, G.A., S. Miyamoto, and J.B. Storey. 1991. Seedling growth and boron uptake of five pecan cultivars. HortScience 26:386-388.

Reid, R.J., J.E. Hayes, A. Posti, J.C.R. Stangoulis, and R.D. Graham. 2004. A critical analysis of the causes of boron toxicity in plants. Plant Cell Environ. 27:1405-1414.

Scott, L.E. and A. Schnader, A. Lee. 1947. Effect of alternating conditions of Boron nutrition upon growth and Boron content of grapevines in sand culture. Plant Physiol. 22:526-537.

Tsadilas, C.D. 1997. Soil contamination with boron due to irrigation with treated municipal waste water. p. 265-270. In: R.W. Bell and B. Rerkasem (eds.). Boron in soils and plants. Kluwer Academic Publishers, Dordrecht, The Netherlands.

Yermiyahu, U., I. Faingold, P. Sarig, A. Stronza, R. Keren, S. Soriano, and E. Zipilevich. 2002. Boron toxicity of grapevines: Final report project 302-0256-01 [in Hebrew]. Chief Scientist of Ministry of Agriculture, Bet Dagan, Israel.

Yermiyahu, U., R. Keren, and Y. Chen. 1995. Boron sorption by soil in the presence of organic matter. Soil Sci. Soc. Amer. J. 59: 405-409.

Yermiyahu, U., R. Keren, I. Faingold, Y. Cohen, H. Yehezkel, and D. Shmoel. 2003. Response of pepper to boron and salinity under greenhouse conditions. Acta Hort. 609:149-154.

Yutal, Y. 1990. Leaching of boron and chloride from soils of the Jordan Valley as a function of infiltration rate [in Hebrew]. The Hebrew University of Jerusalem, Master's thesis. 